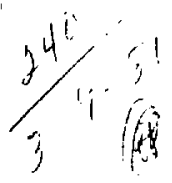

$$
\begin{array}{r}
0.2 .399 \\
R-2598
\end{array}
$$

\title{
MASTER \\ Radon-gas extraction and counting system for analyzing radon and radium in groundwater in seismically active areas
}

K. Knauss

December 8, 1980

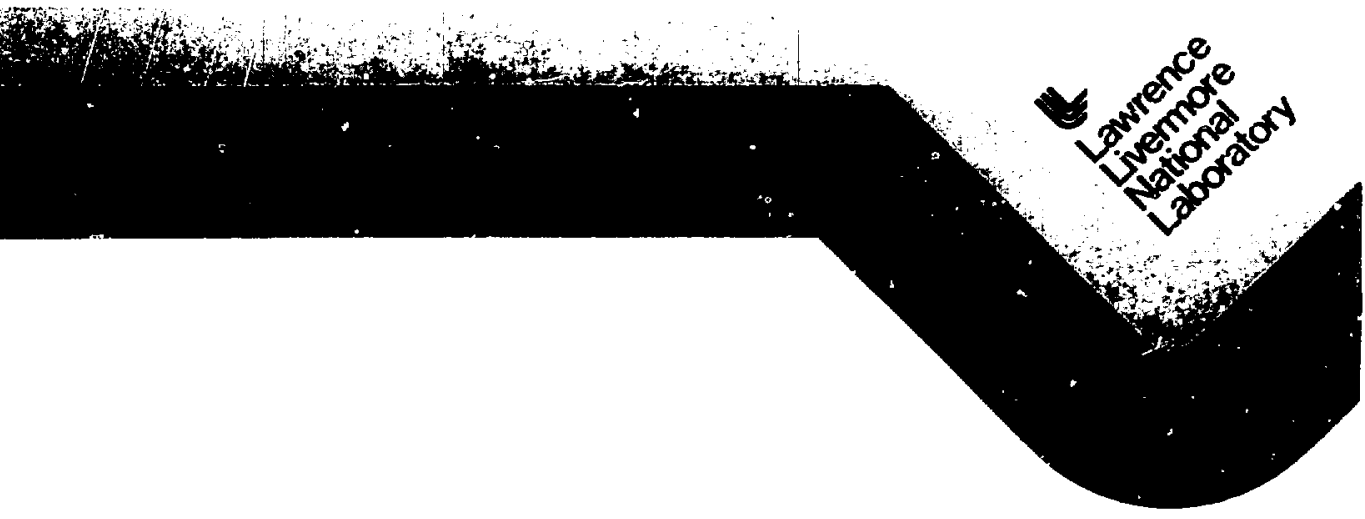




\title{
Radon-gas extraction and counting system for analyzing radon and radium in groundwater in seismically active areas
}

\author{
K. Knauss
}

Manuscript date: December 8,1980 
Abstract

Introduction .

Description of the Apparatus

Extraction Boara.

Transfer Board

Sample Containers

Scintillation-Counting Cell

Counting System

Operation

Sample Collection

Extraction Process

Transfer Process

Scintillation Counting

Performance Characteristics and Efficiency

Calculations

Measurements of Groundwater Radon in the Livermore Area

Historical Perspective of Radon Measurements

in Earthquake Prediction

Radon Levels in Livermore Groundwater . Corclusions

Acknowledgments.

References

Appendi 


\section{RADON-GAS EXTRACTION AND COUNTING SYSTEM FOR}

\section{ANALYZING RADON AND RADIUM IN GROUNDHATER}

\section{IN SEISMICALLY ACTIVE AREAS}

\section{ABSTRACT}

A high concentration of radon in groundwater has attracted rezent attention as a precursor of seismic activity. We have constructed a system that extracts and counts radon gas from solid, liquid, and gas sampies. The radon is extracted in a closed system onto activated charcoal. The desorbed radon is then measured in a phosphored acrylic cell by scintillation counting of gross alpha radiation. The efficiency of the total system lextraction pius courting) is $90 \pm 38$ or tetter. Compact design and sturdy construction make the system completely portable and well suited to field operations in remote locations. Results are given for radon and radium in groundwaters in the Liverinore area.

\section{INTRODUCTION}

Recently, radon has gained attention as a potential precursor phenomenon related to seismic activity. We describe an improved extraction and counting system developed to monitor radon in groundwater along the Greenville Fault, following the seismic events of January 1980.

At that time, existing equipment was inadequate. Trere were no extraction IInes available at the nama-counting facilities in the Nuclear Chemistry Division. An extraction $\perp$ ine and scintillation counter at Hazards Control had been used two years before but had subsequently been dismantieo. Furthermore, none of the equipment was suitable for field use. Continuous monitors have been deveioped for field use, but they are all prototypes, i.e., not comercially available, and typically cost up to $\$ 15,000$ or mare per unit. ${ }^{1-3}$ The more economjcal method to monitor groundwater radon is via discre.e sampling, and this is the method we used.

Our system differs from the old Harards Control syster. The larter consisted of a single-pass glass and rubber tubing design, where radun was 
adsorbed on activated charcoal at dy-ice temperature using helium as 3 carrier gas. The radon was then desorbed at $400^{\circ} \mathrm{C}$ and drawn intn a glass, zinc sulfide scintillation cell (made bj Johnson Laboratories, Baltimics, 1:Dt by a peristaltic pump. This lusic desijn nad seen copied more or less directif fror Lucas. 4 hithough the syster wriker seasonably well in the iaboratory, it was not suitable for field sec.

Our new syster. incorporates some ver's straigheforward design change: that greatly improve overall efficiency and result in a more $r$ ugged, more easily operated system. It employs stanness-steei tubing, closed-loop gas recirculation, Quick-Connects or the charcoal column and scintillarion cell, and ci"nponents mounted on a pal: of aluminum boards. The new counting system uses a cormercially avaliable phrtomultiplier.scaler and low-cost acrilic piastic scirtilation cells, whoch we designed and constructed.

Althusgt. developed initially for a specif lc application, the equipment hais a grenerul application ir monstoring radon. Radon is a naturally occurelng radioactive gis that exists primarily as the longest-lived 1sotope ${ }^{222} \mathrm{Rn}$, with a $3.8-$ daj lalf-12fr. It is a member of the $238 \mathrm{U}$ decay-series and is the immed: ate daughter if $226 \mathrm{Ra}$, with a half-lif: of 1620 vears. As a noble gas, it is chemically lnert and hence offers the ability to act as a tracer for studying rany natural processes in geology, geochemistry, f:'drology, metcorology, and ocranography. It has also been used in eyploration. This report give: rxamplei rf these applications, and also oresents an historicai perspective of the attention given to radon as a potential precursur phenomenon reicted $t^{-}$seismic activity.

\section{DESCRIPTION OF THE APPARATUS}

EXTRACTION BOARD

Figure 1 shows the extraction Jine. It consists of a closed loop that recycles the carrier gas (helium) through the sample. This prccess reguires a much smaller volume of gas than does a single-pass system.

The carrier jas plus other gases exiting the sample bottle contain $\mathrm{CO}_{2}$ and water vapor which must be removed before passage of the gases over the charcoal adsorber. For this purpose the line contains an acrylic tube 


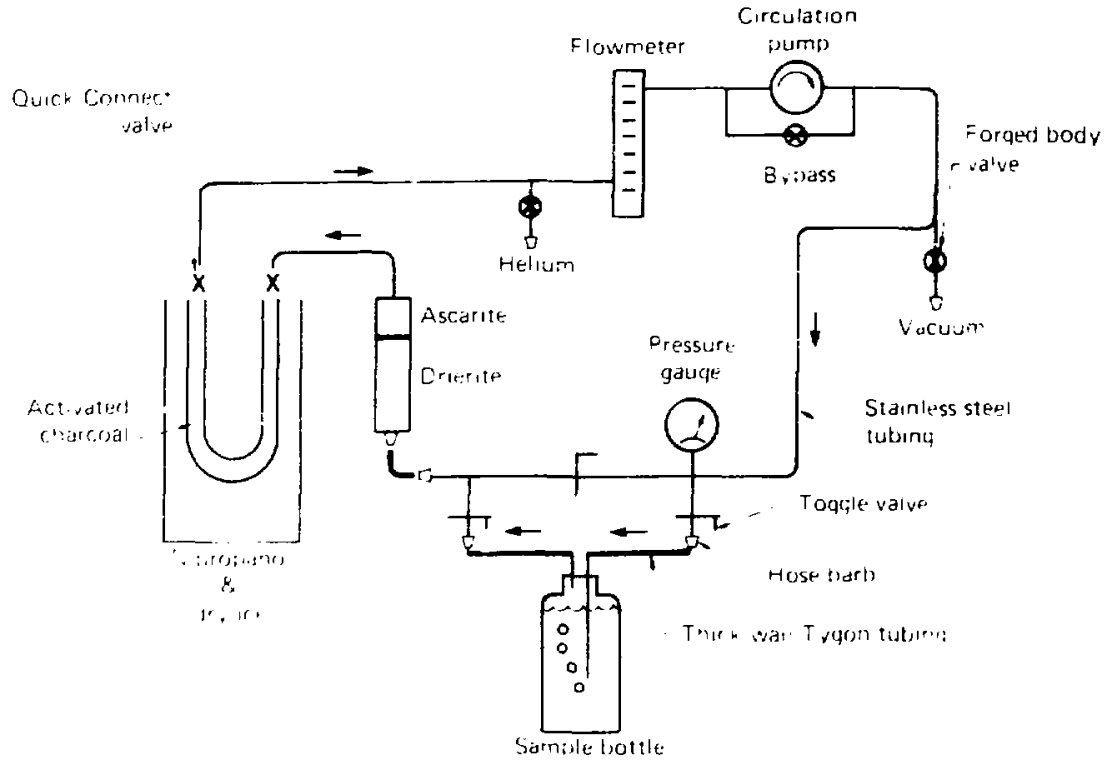

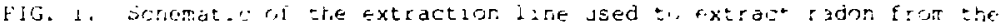

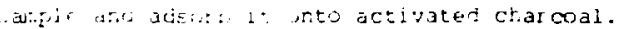

3.4-2.. \%.d. I2 li. Lorg1, Eitled with lndicatiny Drler:ta lansydrous

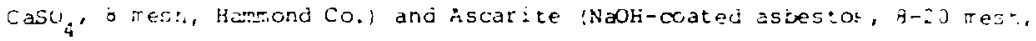

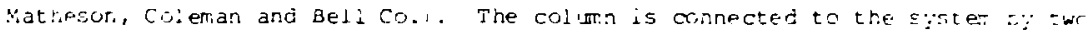
Cajon iltra-Tor f lttings.

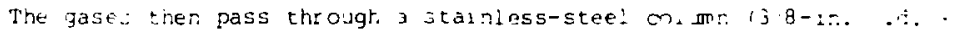
i5 1:. long, which is formed in a U-shaif with approximateig: ir. rotwer.

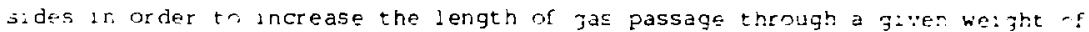
crarcoal. The witun is approxitatel $\because 2 / 3$ full of activaiec comnut charooa: (6-14 mesh, Flsher Screntific Co.) and plugged with jazs woo! to hol: tha charcuaj in place. The colmn is Eltted with two Swage:ock 2ick-zontect: with viton o-rings. To adsorb radon gas, the colinn iz cooled to dry-ice temperature $\left(-78^{\circ} \mathrm{C}\right)$ by immersion in a cooling batt mace of a slary of dry ice and n-propano: held in a Dewar flask (3 in. i.d. . 12 in. 1ong). 
A circulation pump Matal Bellows Co.l then tetsens the carrier gas $=$, the sample pottle. The flow rate is controlled oy a bypass raive arcurd the circulation pump circuit and $\vdots$ inonitored by a hel imn-calitrated fl zwmeter (Fischer-Porter Co.) and a pressure gauge (Matheson Co.). The syster is $3:$ : hooked to a helium source and a vacuum pump.

The syster as designed zonsiste primarily of iuning, fittings, ard $\because]^{*} \because$

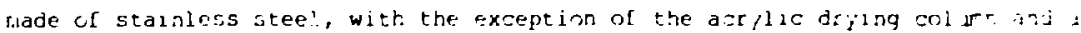
shert section of thick-ball teinforced Tygon tubing. Zhe later is on nne enj of the drying colum to allow its easy removal. All lines nave beer kept th is minlmum lengti for compact design. All romponents lincluding the clrcitation pump) are mounted on an aiumbnum buard measistang 21 ir. long, $241 \mathrm{n}$. ragh which is weldej to an 8-in. al uninum base platr.

TPANSFEK BUARL

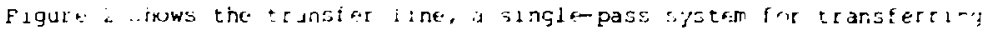
rado: trom the charcria: to the acintllation cai: .

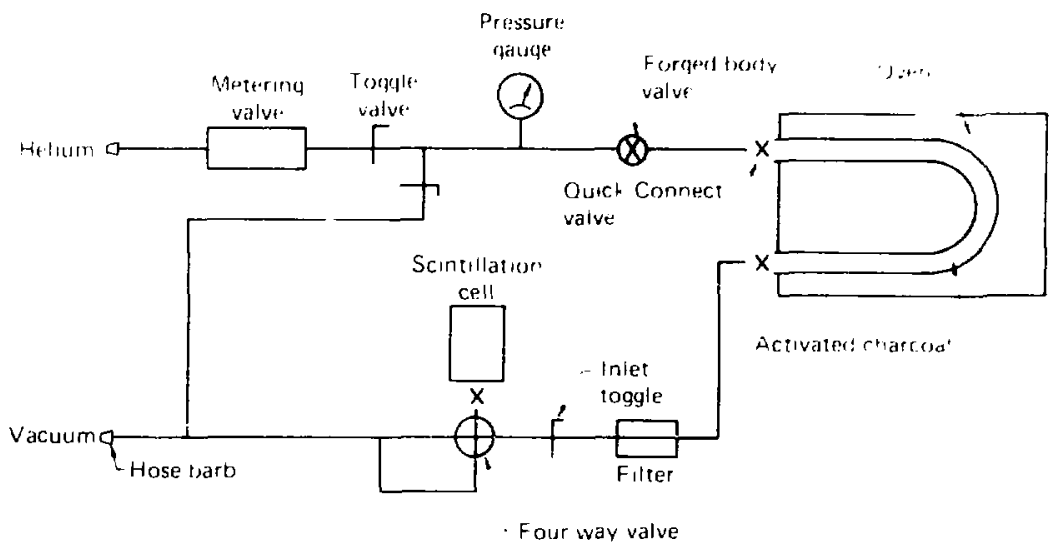

FIG. 2. Schematic of the transfer line used to transfer radon from the activated charcoal column to the scintllation cell. 


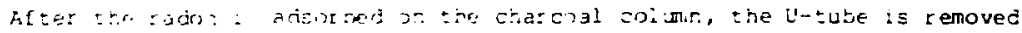

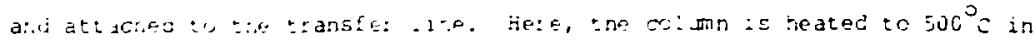

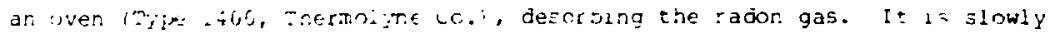

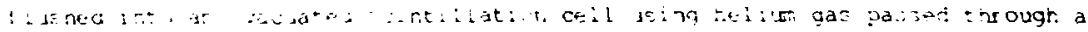

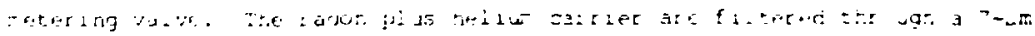

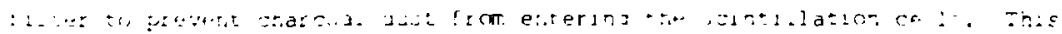

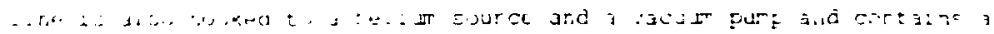

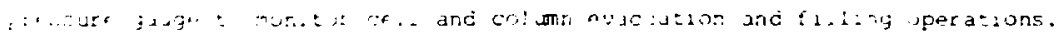

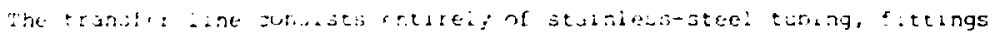

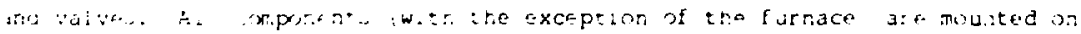

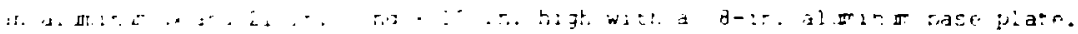

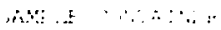

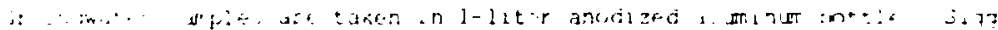

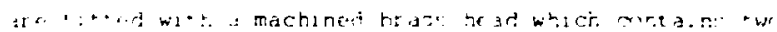

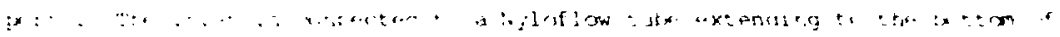

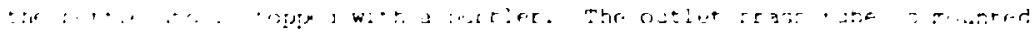

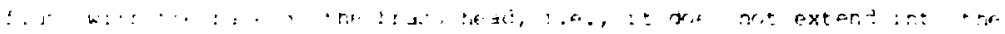

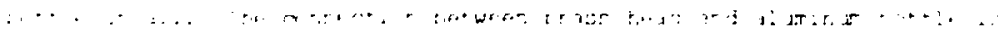

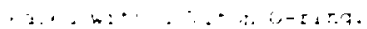

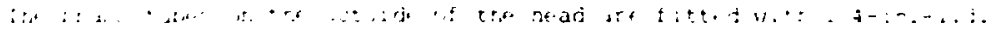

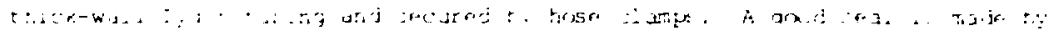

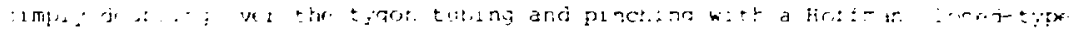

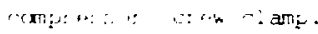

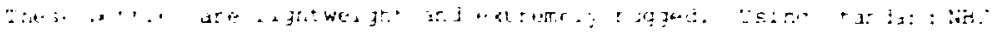

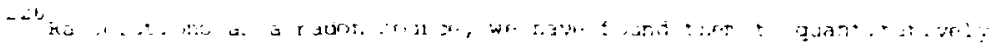

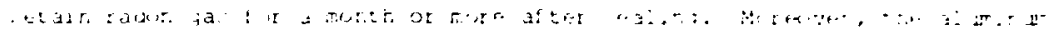

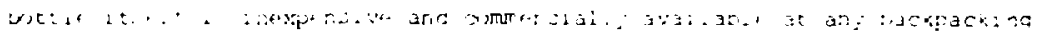

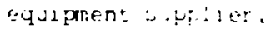

SLIII'ILLATIU:-CUUNTING CELI.

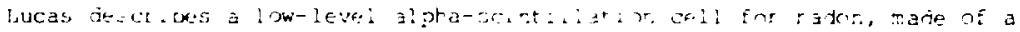

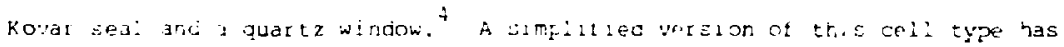

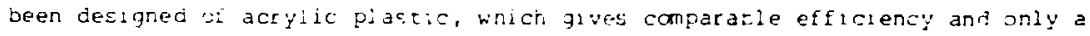
E:ightly rijber iackgrounc. Howejus, it can be made at a f action of the cost. 
Figure 3 shows a schematic of the scintillation cell. The cell is constructed entirel; of acr $f$ lic plastic (ultraviolet transmitting) using 2-in.-o.d. pi:e and 1/4-in. and 1/2-ir. sheet. The nominal internal volune is $100 \mathrm{cc}$.

The ce'l is constructed by first applying a coatir.y of optically transparent crystal grease tc all inside surfaces. Then, silver-activatod zino sulfide powder (nickel-poisoned to reduce afterglow, 20-70 $\mathrm{\mu m}$, Nuclear Enterprises, Inc.) is poured into the cell to totally coat t.te inside. Fxress powder 's removed by gently tapping by hand and then bi wing $; i$ th a stream of helium gas. A Swageisck Quicx-Connect fitting is epoxied in the neck of the

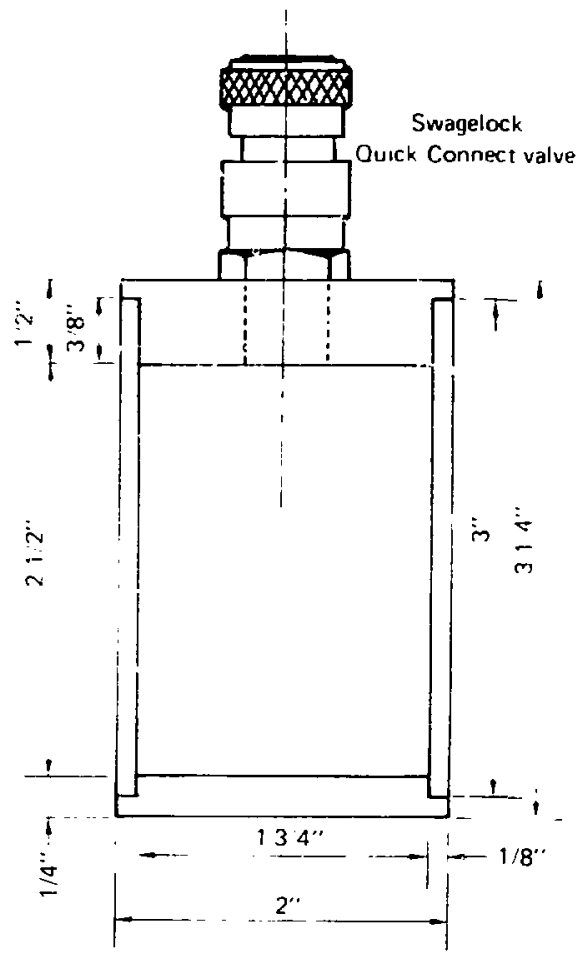

FIG. 3. Schenatic of the scintillation-counting cell. The cell is constructed of acrylic plastic. 
ce1. Finaliy, "he cell is wraped with aluminum foll and then black electrica: tape to make it light-tighi. Only the window that rests on the photomultiplist is left. uncovered by for: and tape.

COUNT ING SYSTEM

Durlng the first month of operation, whlle the extraction and : ansfer lines were belig debugged and a reliable analytical scheme devised, an vid zounting system or 1 ginall $\dddot{j}$ used by Hazards Con'rol sone years zgo ws resurrected and used for the radon counting. The counter consisted of $A$ counting chamber, piotomultiplier, preamp, amp, scaler, timer and nigh-visirage pover supply. After replacing severai conpsnents with ones borrowed from Instrument Loar, a usable $s$ :em evolver. However, it suffered from a spurious notse problem and.. E each sample had to be monitored for many sho: c count perlods in order tu verify a stable count rate. It becare otvious very rapidly that another count,r would be $r \in$ zulred. Forlirately. irexpensive c mercial counters with th.s basic design are available and one was acguired fi. this re:s system.

The new commercial counter, which has been in use since June 1780 , 13 a two-channel radon counter (DRC-MK6. Applied Techniques Co.). Inis system consists of two separate counters, eacn corprisec of: courting chamber with cloth hood ar. PVC cap, RCA 6342A photomultiplier tube, Tennelec :55A preamp, and a power supply and 7-decade counter. Thes two ceunters have a zomon crystal-controlled 7-decade timer. The unit was designed $b_{\ddot{y}}$ sob Lupton of Lamont-Doherty Geological Observatory of Columbia University. Figures 4-5 illustrate the operating characteristics of the photomultipl:irs and ininvoltage power supply. The two-channel couriter 15 compact $(i 7.17 \times 161 \pi$.) and lightweight $(15 \mathrm{lb})$, and is enclosed in a case with handles. In addition to being completely portable. It inay be batsey-operated for field use in remote areas.

The principle of operation is as follows. The alpha particles produced from the decay of ${ }^{222} \mathrm{Rr}$ and $i$ ts daughters ${ }^{218}$ Fo $(3.05-m i n$ half-1ife) and 214 Po (163.7-us half-life) produce scintillations in the phosphor coating on the inside of the counting cell. Photons of ligtt are en:tted wich excitt the photocathode of the photomultiplier tube, yielding an electron. For each 

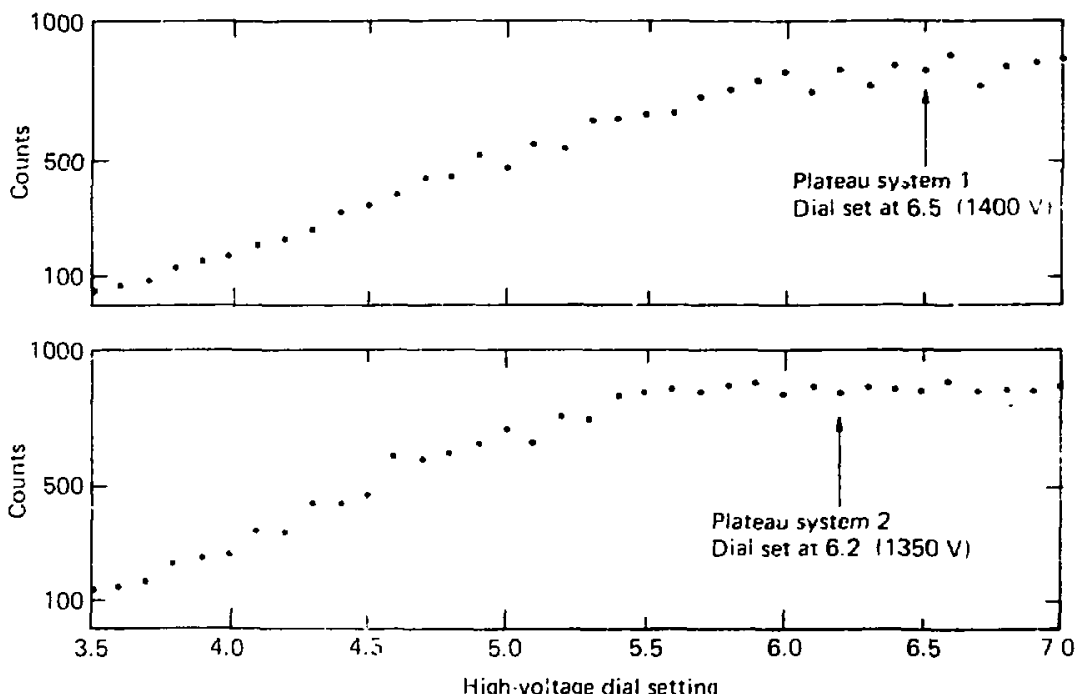

FIG. 4. Operating characteristics of the RCA $6342 \mathrm{~A}$ photumultiplier tube fot systems 1 and 2 , showing how operating voltage was set in the plateau region.

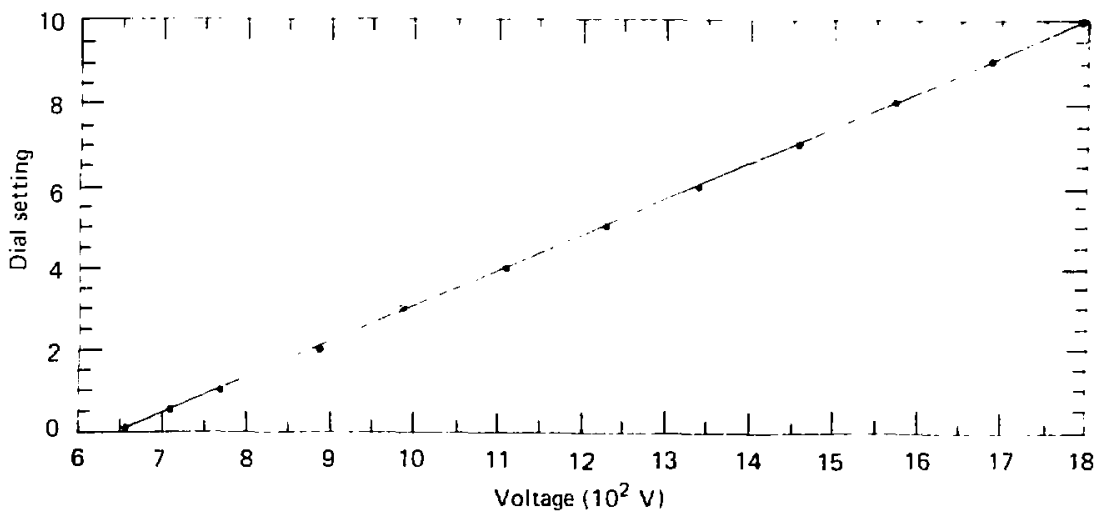

FIG. 5. Calibration line of the high-voltage power supply. 
electron given off, approximately six electrons are $r \in$ leaseo from each of the photomultiplier tube's ten dynodes. This electron amplification releases a shower of electrons collected by the anode, and in this way a pulse foris. The preamp amplifies the pulse from the photomultiplier tube anode, and the output is a long-tailed pulse, 0-4 $\mathrm{V}$ positive. The counters are set to reject pulses less than $250 \mathrm{mv}$ and they can resolve single pulses up to a counting rate of 10,000 pulses/s.

OPERATION

SAMPE COLLECTION

Gas samples may be acquired in any appropriate vessel containing an inlet and an outlet to allow circulation of the helium carrier jas. Aiternativeiy, on vissels with only one port, the gas may be expanded into an evacuated extraction board and then circulated. The extraction board contains a sample bypass toggle valve for this purpose. In this case, ise extraction eff $1=1 e^{2} c_{j}$ will naturally be somewhat lower.

Liquid samples or solutions resulting from the dissoiution of solids may be conveniently acquired and analyzed in the aluminum bottles previously described.

Groundwater samples are collected by drawing the sample into an evactated sample bottle. At springs, this is accomplished by submerging tive Tygon inle: tube. At well sites, a port and valve are installed directly at the wall head. Water is passed through a Nalgene bottle which is kept gas-fret by introducing the water at the bottori and allowing only a small opening at the top. The water sample is then taken from this bottle in the same manner as for a spring site. Wells are pumped for $20 \mathrm{~min}$ prior to sampling to empty tine well casing and provide a representative sample.

\section{EXTRACTION PROCESS}

The sample bottle, with hose clamps still on, and the U-tube are attached to the board and the line is alternately evacuated and filled with helium three times, in order to flush the system. The togsles to the sample are closed and 
the husa clamps removed. The U-tube is ther: croled for $10 \mathrm{~min}$ in the dry-ice bath. The pressure is returned to 1 atn with telium and then the toggles to the sample are opened. The circulation pump is turned on ano the Elow rate adjusted to $2 \mathrm{l} / \mathrm{min}$, and the stripping process is continuej for $30 \mathrm{~min}$.

After stripping, the toggles to tha sample are closed and the $\mathrm{U}$-tube is evacuated for $30 \mathrm{~s}$ while $\mathrm{still}$ cold. The evacuated $\mathrm{U}$-tube is then disconnected froil the extraction board.

TRANSFER PROCESS

While the extraction process is taking place, the scintillation cell is attached to the transfer board and flushed three times with heliun. It is then evacuated for $30 \mathrm{~min}$. The four-way valve is turned and the inlet toggle closec so as to isolate the cell from the rest of the line. The rest of the 1 ine is ieft oper to vacuum.

The $\mathrm{U}$-tube is brought to room temperature and attached to the boar $\mathrm{d}$ and evacuated for $1 \mathrm{~min}$ in order to remne air. I.ittle or ne radon is lost y evacuating the charcoal at room temperature, provited the evacuation is nade through the column outlet. The column outlet is the end of the column through which radon gas exited during the extraction process.

The U-tube is inserted in the preheated oven for $10 \mathrm{~min}$ and brought to $500^{\circ} \mathrm{Z}$. The inlet toggle is opened and the system allowed to stand for an additional $5 \mathrm{~min}$. The radon is slowly backflushed from the U-tube into the scintillation cell with helium carrier passing through the metering valve. During this filling process the flow of helium through the $u$-tube is reversed from $i$ ts direction during extraction. Immediately upor. filling, the scintillation cell is removed fram the transfer board.

After the cell is removed, and while the $\mathrm{u}$-tube is still at $500^{\circ} \mathrm{C}$, the charcoal is further flushed with helium for $5 \mathrm{~min}$ in o:der in assire that all radon is desorbed prior to the next sample extraction. The U-tube is then brought to room temperature and reattached to the extraction board. Both boards are flushed three times with helium and evacuated for at least $1 \mathrm{~h}$ before running the next sariple. Both boards are pressurized to +5 psig with helium overnight to assure they remain grs-tight. 
Tise scintillation cells are placed in the courting chanber and remait. there for $2-1 / 2 \mathrm{~h}$ prior to councing. This allows the two alpha-emitting Po daughters to grow into transient equilibriw with the $R=$ in the ceil. It also illows the effects of stray izght on the scintillation sell to ciminisn and the cell to stabilize with respect to the negative charge induced by the potential on the photocatroce of the photomultiplier sube. Because the counting chambers are covered with a heavy black cloth, no light from the room may strike the photarultiplier. This allows the high voltage to remain on at all times.

The final count is initiated $2-1 / 2$ h after filling the cell. The duration of each final count depends on the sample activity, but is routinely between 30 and $120 \mathrm{~min}$. Recordings of total counts and time elapsed ar $\pi$ ade periodically over this time interval to verify a stable count $r$ ate.

Afte: the final count, the scintillation cells are flushed repeatedly with helium and then evacuated for at least $1 \mathrm{~h}$. The cells are rotated ir. sequence such that at least one day elapses between removal of the last sample and initiation of the cell background determination pior to the next sample.

\section{PERFORMAIIF: CHARACTER STICS AND EFFICIENCY}

We determined the overall system efficiency separately for each scintillation cell by using an NBS standard ${ }^{226}$ Ra solution as a radon source. Three such standards were made up using distilled water in the sane type of alunisum bottles used for groundwater samples. This overall efficiency includes: the extraction efficiency, the transfer efficiency and the counting efficiency. The overall system efficiencies for the scintillation cells are shown as follows:

Cell

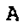

B

C
Efficiency (8)

$\begin{array}{ll}88.9 \pm 1.7 & (n=4) \\ 89.7 \pm 2.3 & (n=4) \\ 91.3 \pm 3.3 & (n=4)\end{array}$


There is no relationship botween equilibration time (i.e.. length of time between extractions during which the radon grows in toward secular equilibrim) and the derived overall system efficiency. This offers an infication that the sample bot.tles are quantitatively retaining the $r$ adon within them for periods even up to one month.

we getermined the extraction efficiency by making two successive 30-min extractions from the same standard solution and comparing the recovered radon activities. It was found that the first $30-\mathrm{min}$ extraction had removed 98.88 of the radon.

The $t r a n s f$ or efficiency was determined by sweeping the $r$ adon gas desorbed at $500^{\circ} \mathrm{C}$ from the charcoal culunn used in a standard extraction into two successive scintillation cells and comparing the recoverea radon activities. It was found that the r.rst transfer had swept 99.48 of the radon from the charcoal. Apparently, the bulk of the efficiency loss is due to the counting effiriency of the scintillation cell and courter and rot to the extraction or transfer prucesses.

The ceil backgroundr are constantly monitored by filling the cells with helium and counting overnight prior to each sample run. The background is that part of thr weasured activity due to the counting cell itself, and to a very small degree, to the electronic noise inherent to the photomultiplier tube. It is due to any alpha-particle-emitting substance present in the crystal grease, zinc sulfide, acrylic plastic or other construction materials, or in the counting chamber itself. The cell backgrounds for these counting cells are $.35 \pm .04$ counts per minute (cpm).

There are two types of blanks: a system blank and a bottle blank. The system blank refers. the radon act, ity contributed by the extraction and transfer buards themselves. The bottle blank refers to the radon activity contributed by the sample bottle. These blanks are due to material containing trace amounts of ${ }^{226}$ Ra or through which radon can diffuse into the system from the atmosphere.

The system blank was determined by short-circuiting the sample inlet anc outlet toggles (there is a bypass toggle for this purpose). It should be noted that the $s^{-t e m}$ blank was measured in such a way so as to assess the memory effect of the board. Any radon present in the system is extracted by following, step by step, the normal operational nrocedure. A standard solution was $r$ un first, the board was flushed a..d evacuated for $1 \mathrm{~h}$ and then 
Tia scintillation cells are placeo in the counting chamber and zemain there for $2-1 / 2 \mathrm{~h}$ prior to counting. This allowe the two alpha-emitting Po daughters to grow into transient equilibrium with the Ri. in the cell. It also allows the effects of stray light on the scintillation cell to diminisi. and the sell to stabilize with respect to the negative charge induced by the potential on the photocathode of the photomultiplier tube. Because the conting chambers are covered with a heavy black cloth, no light from the room mal strike the photomultiplier. This allows the high voltage to remain on at all times.

The $f$ inal count is initiated $2-1 / 2 \mathrm{~h}$ after filling the cell. The duration of each $f$ inal count depends on the sample activity, but is routinely between 30 and $120 \mathrm{~min}$. Recordings of total counts and time elapsed are rade Earicdically over this time interval to verify a stable court $r$ ate.

After the final count, the scintillation cells are flushed repeatediy with helium and then evacuated for at least $1 \mathrm{~h}$. The cells are rotatedir. sequence such that at least one day elapses between removal of the last sample and initiation of the cell background determination prior to the next sample.

PERFORMANCE CHARACTERISTICS AND EFEICIENCY

We deternined the overall system efficiency separately for each scintillation cell by using an NBS standard ${ }^{225}$ Ra solution as a radon source. Three such standards were made up using distilled water in the same type of aluminum bottles used for groundwater samples. This overall efficiency includes: the extraction efficiency, the transfer efficienc $;$ and the counting efficiency. The overall system efficiencies for tince scintillation cells are shown as follows:

\begin{tabular}{|c|c|}
\hline Cell & Efficiency (8) \\
\hline$\therefore$ & $88.9 \pm 1.7$ \\
\hline B & $89.7 \pm 2.3$ \\
\hline c & $91.3 \pm 3.3$ \\
\hline
\end{tabular}


There is no relationship between equilibration time li.e., length of time Detween extractions during which the radon grows in toward sec 1 ar equilibrim) and the derived overall system efficiency. This offers an indication that the sample bottles are quantitatively retaining the radon within $t$ rem for periods Gven up to one month.

We determined the extraction efficiency by making two successive 30-min extractions from the sane standard solution and comparing the recovered radon activities. It was $f$ cund that the first $30-m i n$ extraction had removed 98.8 of the raden.

The transfer efficiency was determined by sweeping the $t$ adon gas desorbed at $500^{\circ} \mathrm{C}$ from the charcoal column used in a standard extracition into two Euccessive scintillation cells and comparing the recovered radon activities. It was fo: ind that the first transfer had swept 99.48 of the radon from the charcoal. Appal əntly, the bulk of the efficiency loss is due to the counting efflciency ol the scintiliation cell and counter and not to the extraction or transfar processes.

T:Ac Cell taskgrounds are constantly monitored by filling the cells with bel:um and counting overnight prior to each sample $r$ un. The background is sat part of the measured activity due to the counting cell itself, and to a :rr imai degree, to the electronic noise inherent to the photamultiplier turs. It 1 i due to any alpha-particle-emitting substance presont in the ayotal grease, zinc sulfide, acrylic plastic or othe: constructson mater-als. or in the counting chamber itself. The sell backgrounds for these counting cells are $.35 \pm .04$ counts per minute (cpm).

There are two types of b.anks: a system blank and a bottle blank. The system blank refers to the radon activity contributed by the extraction and transfer boards themselyes. The bottle blank refers to the $r$ adon activity contalbuted by the sumple bottle. These blanks are due to material containing trace amounts of ${ }^{226} \mathrm{Ra}$ or through which $\mathbf{r}$ adon can diffuse into the system from the atmosphere.

The system blank was determined by short-circuiting the sample inlet and outlet toggles (there is a bypass toggle for this purpose). It should be noted that the system blank was measured in such a way so as to assess the memory effect of the board. Ary radon present in the system is extracted oy following, step by step, the normal operational procedure. A standard solution was run first, the board was flushed and evacuated for $l \mathrm{~h}$ and then 
the system blank was determined. This should approximate the effect observed by the second sample run on any particular day. The system blank was found to be approximately 0.14 decays per minute (dpm), which represents about 0.158 of the total sta.idard activity. This percentage is the relative momory offect of the extraction board. A system olank run on an extraction board which had not just been previously used should have considerably less than this activit $\%$, possibly as low as $0.05 \mathrm{dpm}$, which would approxinate the contribution to radon actıvity due to the charcoal aione. 5

The bottle blank is determined by filling an iluminum bottie with distilled water, fi lshing the radon out and then massur 1 ng tha $r$ adon snat grows in over a 1 -montr. period. After suttractirg the cell background and system-blank activity determined above, an additional 0.20 dpti remains, which is the radon actuvity contributed by the bottle and distilied water. Table: sumarizes the performance characteristics for this analytical system.

TABLE 1. Performance characterıstics of the radon extracticn and counting system. Cell background is expressed as counts per minute (cpm), valjes for blanks as decays per minute (dpm).

$\begin{array}{ll}\text { Overall efficiency, } 8 & 89-91 \text { idepending or cell, } \\ \text { Extraction efficiency, o } & 98.8 \\ \text { Transfer efficiency, } & 99.4 \\ \text { Cet: background, cpm } & 0.35 \\ \text { System blank, dpm } & 0.14 \text { or less } \\ \text { Bottle blank, dpm } & 0.20\end{array}$

CALCULATIONS ${ }^{5}$

1. Calculation or overall efficiency (E) a. Calculate cpm ${ }_{x}$ (counts per minute at time of extraction of ${ }^{222} \mathrm{Rn}$ ). $c p m_{x}=\frac{c p m-(b k g+b l k s)}{e^{-\lambda t_{1}}}$ 
where: $\quad c p m=f i n a l$ count rate, comencing $2-1 / 2 \mathrm{~h}$ after filling cell,

bkg = cell background count rate,

blks = count fates of the system blank plus the bottle b. ank,

$=.007553 \mathrm{~h}^{-1}$,

$t_{1}=$ lime in hours between end of radon extraction and iidpoint of final count.

t. Calculate cpm ${ }_{0}\left(\mathrm{cpm}{ }_{x}\right.$ corrected for fraction of equilibrium).

$c p m_{0}=\frac{c p n_{x}}{1-e^{-\lambda t_{2}}}$

where: $t_{2}=$ time in hours between flushing.

c. overail effuciency (E)

$$
E=\frac{c p m_{0}}{q_{\text {std }} \times 3}
$$

where: $q_{s t d}=$ activity in decays per minute (dpm) of NBS 226 Ra standard.

2. Calculation of the amount of ${ }^{226}$ Ra in a sample (dipm ${ }^{226}$ Ra)

a. Flush sample of any ${ }^{222}$ Rn it contains.

D. Let a second generation of ${ }^{222} \mathrm{Rn}$ grow in.

c. Measure ${ }^{222}$ Rn.

d. Calculate cpm $x$ and cpm as shown above.

$$
\text { dpm }{ }^{226} \mathrm{Ra}=\frac{c p \mathrm{O}_{0}}{E \times 3}
$$

where: a:l terms are previnusly defined.

3. Calculation of the amount of excess ${ }^{222} \mathrm{Rn}$ in groundwater $\left({ }^{226} \mathrm{Ra}\right.$ unsupported)

a. Calculate cpm as shown above.

b. Determine dpm $x$ (total ${ }^{222}$ Rn at time of first extraction).

$$
\operatorname{dpm} x=\frac{c p m x}{E \times 3}
$$


the system blank was determined. This should approximate the effect soserved by the second sample tun on any particular day. The system biank was found to be approximately 0.24 decays per minute (dpm), which represents abost $2.15 \%$ of the toial standard activity. This percentage is the celative nemory effect of the extractior wrard. A syster olank run on an extraction boara wich had not just been pre\%lously used shuudd have considerably less than rnis activity, possibly as low as $0.05 \mathrm{dpm}$, with would approxinate the contrbut. or te radon activity due to the charcoa: aione. 5

The bottle blank is determined by filling an giuminum bottie with distilled water, fiushing ine radon out and then measuring the sadon finat grows in over a :-mcntt. period. After subtracting the cell background and

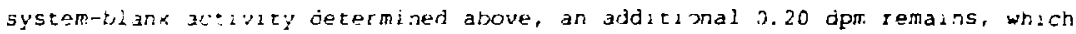

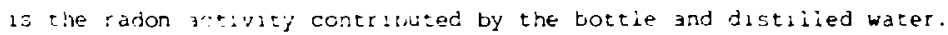

Tavle: $3 y 5+r m$.

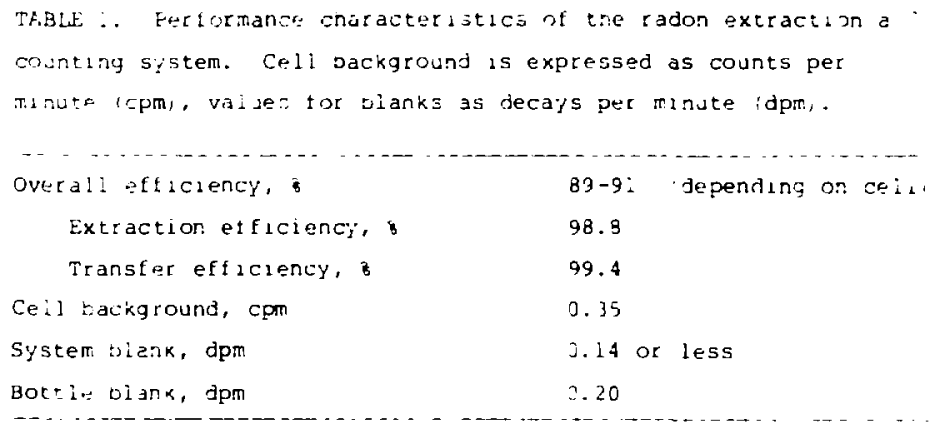

CALCILATIO:IS 5

1. Calculation of overall efficlency $(E)$

a. Calculate cpm $m_{x}$ sounts per minute at time of extraction of ${ }^{222}$ Rni . $c p m_{x}=\frac{c p m-(b k g+b l k s)}{e^{-t t_{1}}}$ 
where: $c p m=$ final count rate, commencing 2-1/2 $\mathrm{h}$ after filling ze11,

bkg = ceil backgrcund count rats,

oiks = count rates of the system tlank plus the bottle blark,

$=.007553 \mathrm{~h}^{-1}$,

$t_{1}=t 1 m e$ in hours between end of $r$ adon extraction and widpoint of final count.

b. Calculate $c m_{0}{ }_{0}\left(\mathrm{cpm} \mathrm{m}_{\mathrm{x}}\right.$ corrected for fraction of equilibritum).

$\mathrm{cpm}_{0}=\frac{\mathrm{Cpm}_{\mathrm{x}}}{1-e^{-\lambda t_{2}}}$

where: $t_{z}=$ time in hours between flushing.

$c$ overall efficiency (E)

$$
E=\frac{c p m 0}{g_{\text {std }} \times 3}
$$
where: $\begin{aligned} q_{5 t d}= & \text { activity in decays per minute (cpm) of NBS } \\ & 226 \text { Ra standard. }\end{aligned}$

$\therefore$ Calculation of the amount of ${ }^{226} \mathrm{Ra}$ in a sample (rom ${ }^{226} \mathrm{Ra}$ )

a. Flush sample of any ${ }^{222}$ Rn it contains.

c. Let a second gereration of ${ }^{222} \mathrm{Rn}$ grow in.

c. Heasure ${ }^{222}$ Rn.

d. Calculate cpm ${ }_{x}$ and cpn as shown above.

$\mathrm{dpm}{ }^{226} \mathrm{Ra}_{\mathrm{a}}=\frac{\mathrm{Cpm}}{\mathrm{E} \times 3}$

where: 11 terms are previously defined.

3. Calculation of the amount of excess ${ }^{222} \mathrm{Rn}$ in groundwater ${ }^{226} \mathrm{Ra}$ unsupported)

a. Calculate $\mathrm{cpm} x$ as shown above.

b. Determine dpm $x_{x}$ (trotal ${ }^{222} \mathrm{Rn}$ at time of first extraction).

$$
d p m_{x}=\frac{c p m_{x}}{E \times 3}
$$




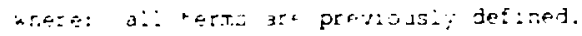

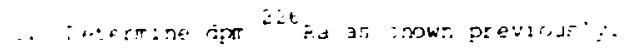

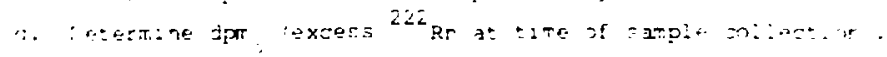

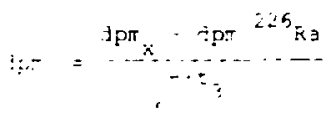

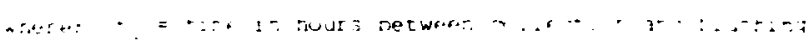

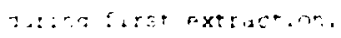

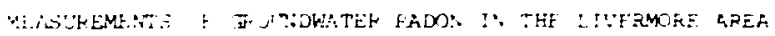

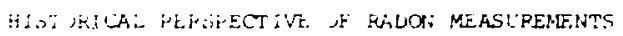

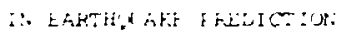

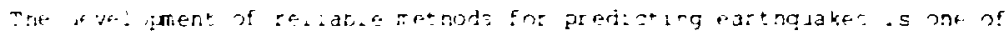

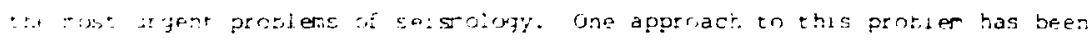

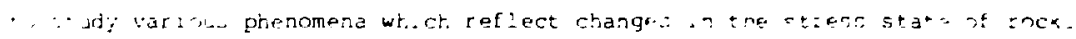

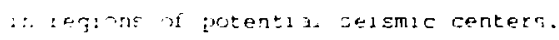

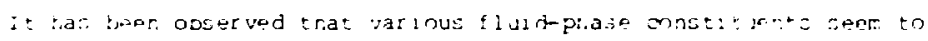

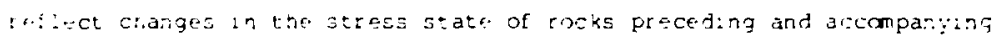
earthguckes. The Russians observer anomalies in the groundrater onntont al:

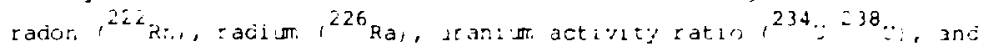
nesim assoc,ated witk. the magnifurie 5.3 Tashkent suent 11966 , and tne magr: tude 5.2 Georgia evert $11973 .^{6-9}$ The Chinese succossfuly gredicted the large, nagnitude 7.3 Halcheng syent 11975 , in part througt the observat:on of groundwater radon anomai ies. 10 The Japarese observed prefursor g ctanges Ir groundwater radon concentratior prior to the aagnitude 7. 3 isu-Oshima-kiukal event (1978). il a radon 1 ncrease was observec 15 an I celandac thermai well prior to an eartinguke. 12 in this coutry, short-term changes 1 n adon emanation, Induced apparently geothermal reservoir during periods of steady geothetmal flaici production. 13 A I arge radon increase occurred prior to the magnitude 4.8 Big Bear Laxe earthquake swarm. 12 
These precursory effects apparent: $\because$ cest lefore rany, and perraps all, snallow earthquakes. Rock jilatancy inelastiz voiunetric increase pr:or to failure) 15 accompanied $b_{j}$ tre iormetisn ard propagation of cracks. idater

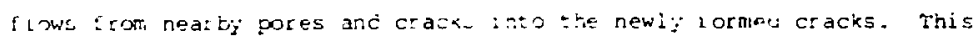

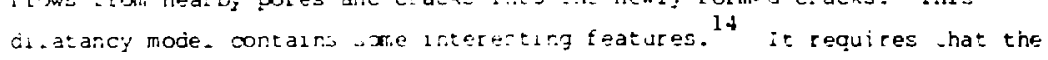

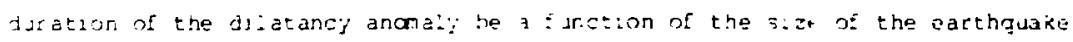

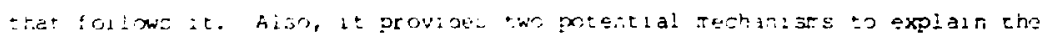
suserver radon increases precursory tr eartig abes. The flast, increase in Suface atsa in tio dilatant region, is an drilkely explanetion of elevater iadon cortent of we:l water due $\because r$. : ne istance ( $)$ the source (6-12 im) and the enxt half-iife of radon. The sar nj mecinanism, lncteased flud fiow in the di:atani, zonf, may suggest thst, imply $r$ continuity, rhe larje-scate

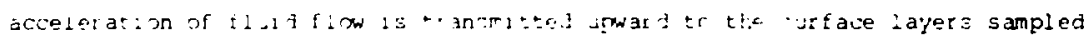

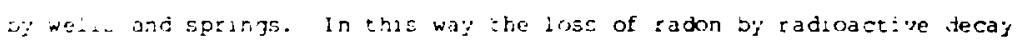

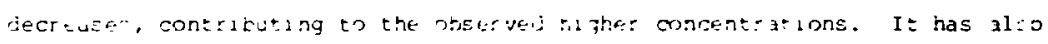
sepr. suggested that the fa:. couge zone : s mechantcally comptiant and strain

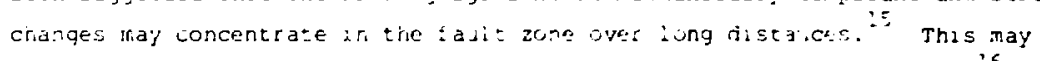
provide jet another mechanism for fihanzlag the . Ocal source inction. "k Despite the fact that this fielo of study is relatively new, it is of suct: importunce that perhaps as many as a dozon groups are now working an varlous

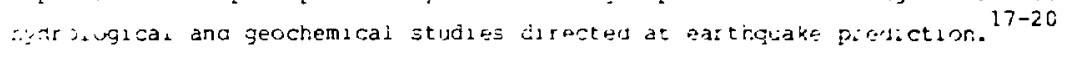

FALS LEVELS IN LIVERMORE GROUNDWATER

Fol:owing the Jariwazy 2980 earthquake.., we constr -ched the radon/radıum iystem and performed a searci to identif $y$ gotential sample points. Wells were seiected for a rumber of reasons, including: proxinity to the Greenville andior has positas Fal:ts, weil-use ipumping patzern, acbi:ty to access line at well head (to acc:l:e representitive wacer sor gas aralysis), we:l jot located in valley-fill alluvilm, ard some anomalous behawor associated with the Januar; events. Since May 1980, Cour wells have bes. routinely minitored Eor zadon ( $\left.{ }^{222} \mathrm{Rn}\right), \mathrm{radi}$ im $\left({ }^{226} \mathrm{Ra}\right)$, and uranium isotopes ${ }^{234}$; and $\left.23 \mathrm{e}_{\mathrm{U}}\right)$. rne wells being monitored are briefly described in the Appendix. To the a.tror', knowledge at this time, no other workers are monitoring potential Ezz:-guake precursors in this area. Dr. C. Y. King (U.S.G.S., Menlo Park) has ixs:- "orltoring soil gas radon on the Calaveras Fault near the Calaveras $\therefore=f y, r$, and this is the nearest point to us on his sampling network. 21 
Bacejo on the work of jcho:z ot ai. :4 :t was tuown fron the empilica:

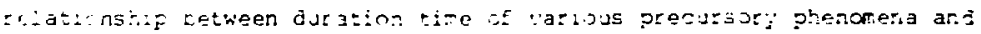

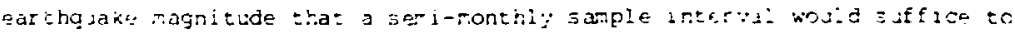
ldentify everts greater thar nagnitude 4 to 4.5, ass ming a detectabie sigial

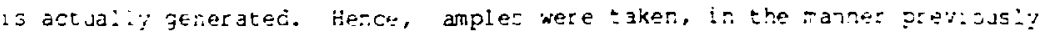

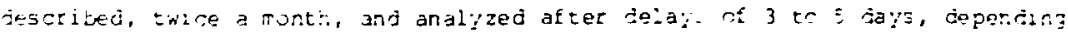

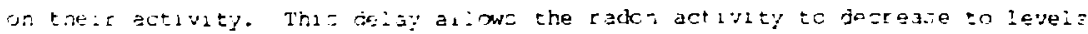

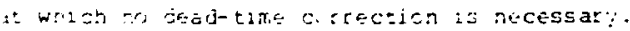

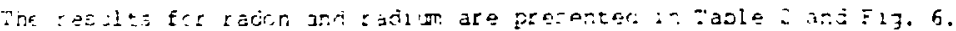

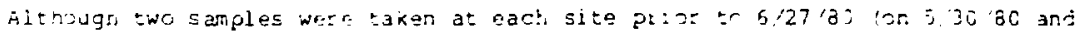

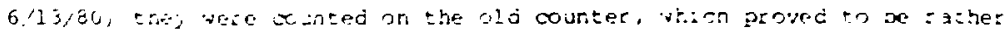

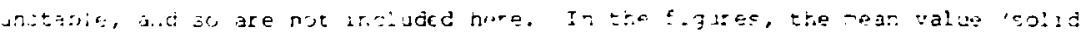

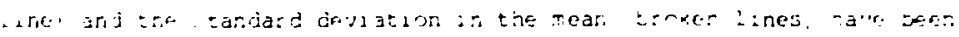

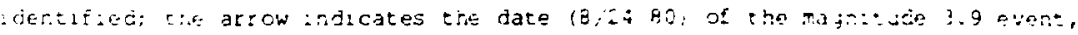

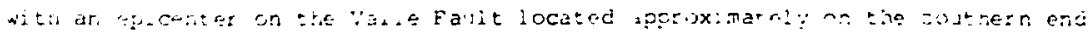

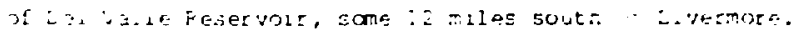

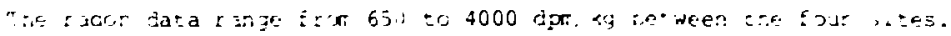

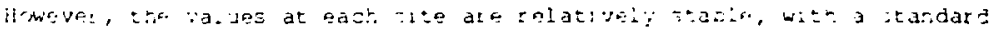

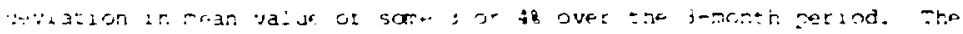

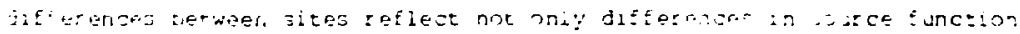

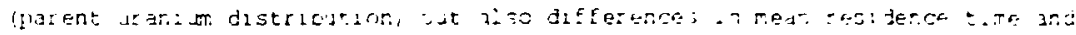

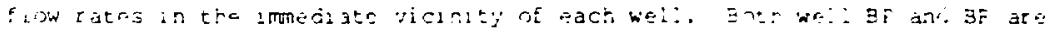

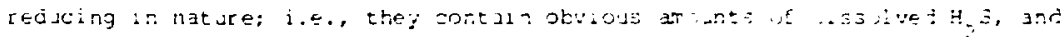

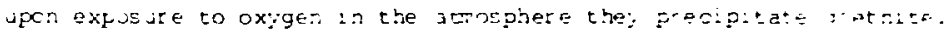

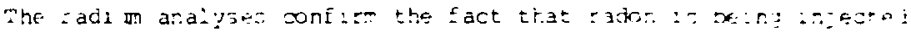

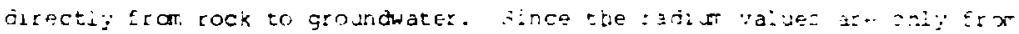

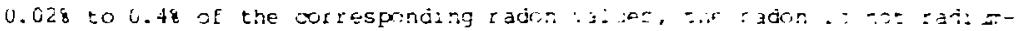
suppotter, This fact simpill

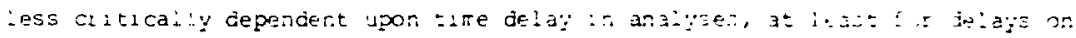

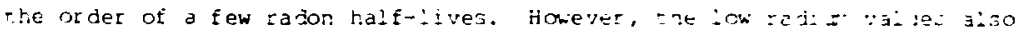

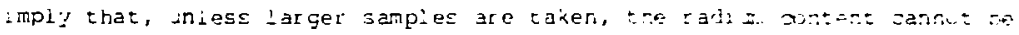

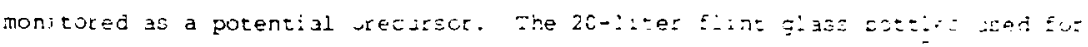

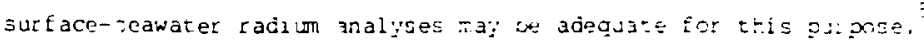


TABLE 2. Radon and radium contsnt of grounowater in four wells in the Livermore area. Samples were taker at semi-monthly intervals from June to September 1980. Concentrations are expressed as decays per minute per $\mathrm{kilogram}(\mathrm{dpm} / \mathrm{kg})$.

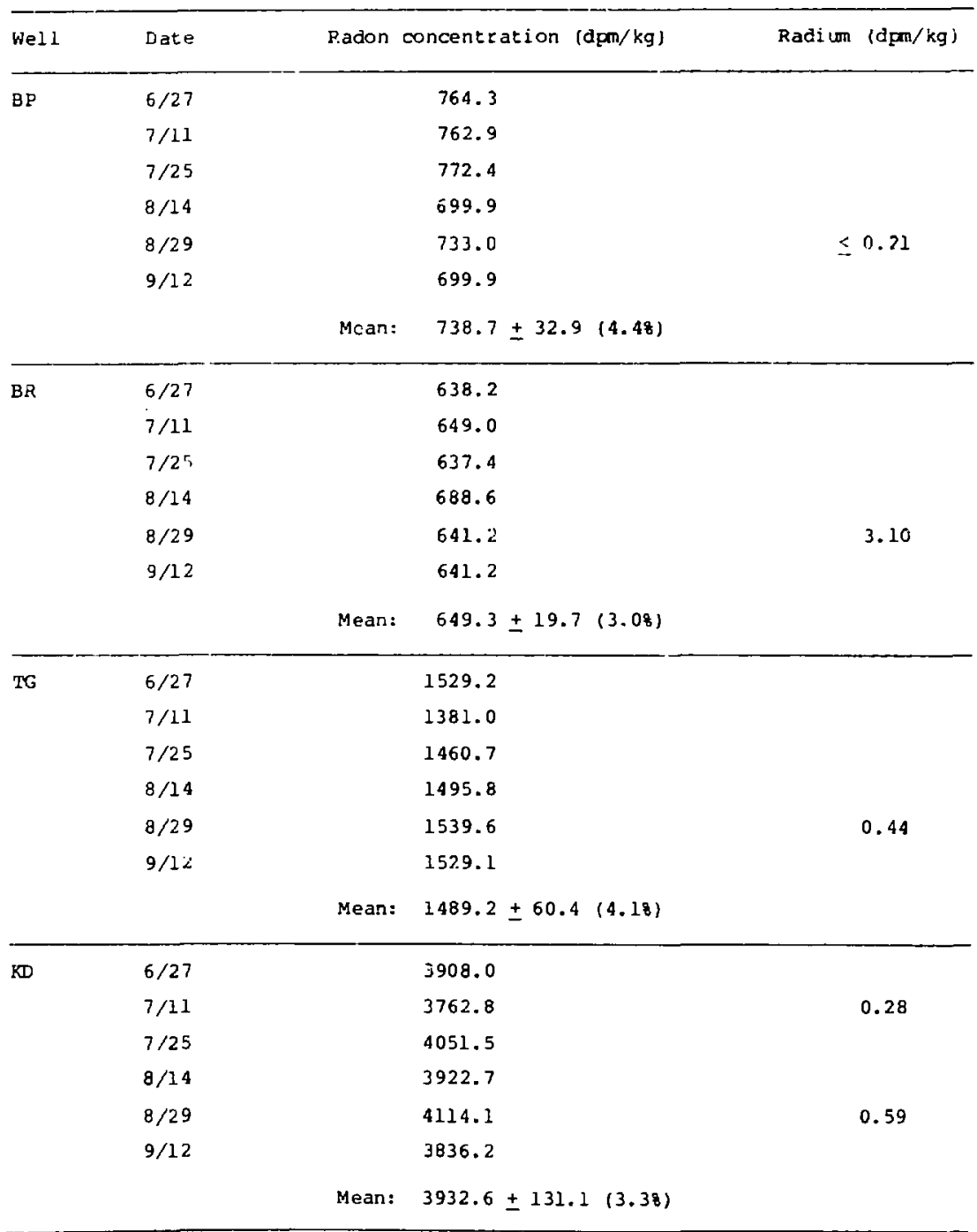



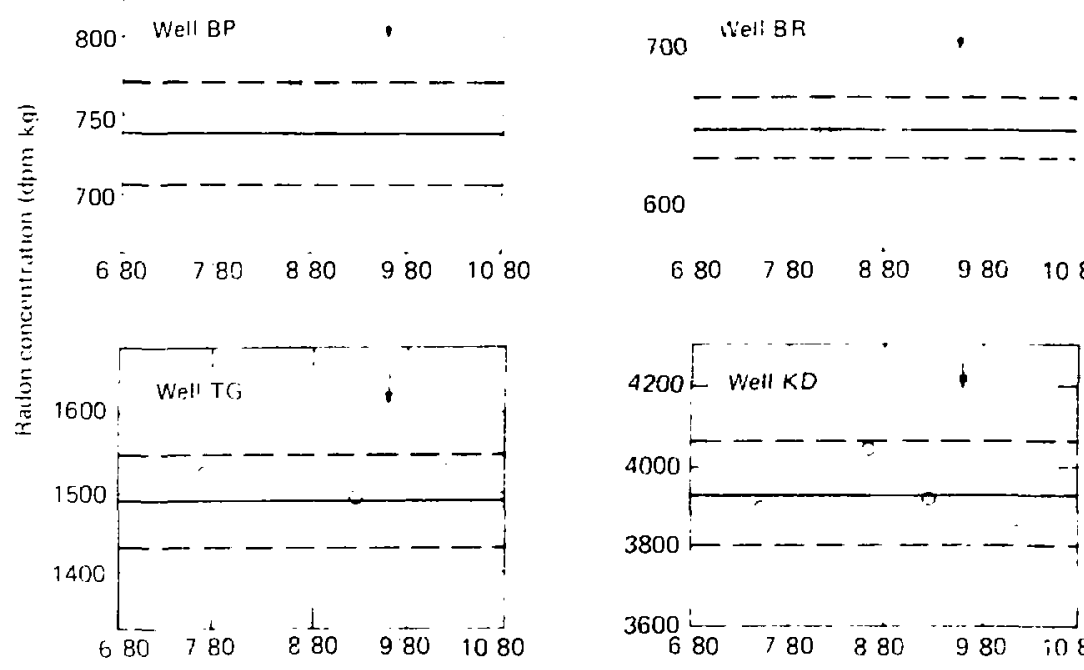

600

$680 \quad 780 \quad 880 \quad 980 \quad 1080$

Date imonth vear:

EIG. 6. kadon concentrations in water from four sanple wells in the :ivermora area. Arrows indicate the date, August 24, 1980, of a seissic event of magnitude 3.9. There is an association between the se $s r . i c$ event and :adon concentration. Radon concentration is expressed as decays per rilnute jer kilogram (dprikg). Solid lines represent mean concentration; broken lines represent standard deviation in the mean.

OE primary interest in a study of this nature is the semporal varuation in $r$ adon at each site and the relationship, if any, between these varlations and seismicity. For the data presented her the observed radon oncentration at each site remains just within plus or minus two standard deviations of the mean value. Hence, no single observation may be considered statistically anomalous in the simplest sense. In many cases documented to date, long term (seasonal?) cycling is noted in the radon content of groundwaters, 12 and so an observation period of only three months is clearly inadequace to esrablish the "normal" variation to be expected at these sites. Long-term monitoring is required to identify these cycles, if they exist here, and then they may be easily filtered from the data. 
Even considering all these caveats, it is most interesting that there is a hint of some association with the only significant seismic event occurring during this 3-month interval. Three of the four sites dispiay sone slight change in $r$ acion content in samples taken from one to six weeks before the event. The most noteworthy case is that of well BR. There is a marked increase (although just at the two-sigma levell in the $r$ adon content of the sample taken 30 days before the event. This site is in srolid bedrock the Tertiary Cicrbo Fm) and is actually a spring, so thexe aze no problems with well-use patterns. The other two sites (Wells BP and TG) display sane slight decrease in racion from one to three sarplings prior to the event, although certainly no statistical significance can be attached to these variations. Precuzsory $r$ adon decreases in groundwaters have been observid previously, and it has been suggested that the direction of change is lelated to the seismic quadrant (compression or dilation). 22 The event occurred on the valle Fault which is subparaliel to the Greenville, Tesla, and Ortigalita Faults, althougn scme 6 or more $\mathrm{mi}$ to the west and not directly linked to chem. ${ }^{23}$ This $r$ ather weak association with the Greenville fault may cause the pcor correlation.

\section{CONCLUS IONS}

A complete systern has been constructed to isolate ana measure radon gas from solid, liquid, and gas samples. The system has been calibrated using NB= standurds, and consistently maintains a total efficiency lextraction plus counting/ of $90 \pm 38$ or better. The compact design and sturey construction make the whole sjstem portable and suit, ble for fieid operations in temote preas.

The system has been used to monitor groundwater radon and $\mathrm{r}$ adi um in the Livermore area. Preliminary results suggest the potential of this approach in monitoring changes in the stress state of rocks in the area. The use of groundwater radon as a potential earthquake precursor is but one of many important ways that radon measurements have been applied in the geological sciences. Some other ways include:

- Determination of recharge temperatures for hydrothermal systens. 24 
- Determination of transport times, fracture permeability, porosity, fiow characteristics, and yolumes of geothermai reservoirs. 25

- Determination of gas exchange rates between surface waters and the atmosphere. 26

- Determination of mixing rates and circulation patterns in surface waters. 27

- Decermination of mixing $r$ ates ard circulation patterns $i r$ the utmosphere. $2 B, 29$

- Determination of the age of groundwaters via He/Rn ratios. 30

- Exploratiur for new geothermal resources and delineation of reservoirs. 31

- Exploration for new uranium ore bodies and delineation of their size and extent. 32

- Deterinnation of the Location of faults covered by thin alluvial cover or which are otherwise masked. ${ }^{33}$

The system described in this report inay be used to address ches. and many other types of problems in the geological sciences where measurements of radon and radium are required.

\section{ACKNOWLEDGMENS}

Encouragement and support were provided by Jim Scheimer. Terry Erven provided the technical coordination, and Larry Marsh fabricated and assembled the extraction and transfer boards. Jack Dellis advised on the construction of the scintillation cells. Carl Lindeken and Ray Szidon provided rechnical advice, a commercial Lucas cell, and the NBS radiur. standards. Jene and Isabelle Dupzyk Loaned the of d counter and provided a vacuum pumf itr the system. All are thanked for their help in this project. 


\section{REFFRENCES}

1. Smith, A.R., Bowman, H.R., Mosier, D.F., Asaro, F., Wollenberg, H.A., zad King, C.Y., Invt jtigation of raden-222 in subsurface waters as as earthquake predictor, Lawrence berkeley Laburator $;$, Berkele\%, CaliE.., LBL-4445 (1975).

2. Noguchi, M. and wakita, H., "A method for continuous measurement of $r a r i o r$. in groundwater for eartinquake prediction." J. Geophys. Res. 82, 1353-1357 (1977).

3. Shapir.J, M.H., Melvin, J.D. and Tombrello, T.A., "Automated radon monitoring at a hard-rock site in the southern Californa Transverse Range: " J. Geophys. Res. 35, 3058-3064 (1980).

4. Lucas, H.F., "Improved low-level alpha-scintillation counter for radon," Rev. Sci. Instru. 28, 680-683 (1957) .

5. Mathieu, G.3., "222 Rn- ${ }^{226}$ Ra technique of analyses," in Transpert and Transfer Rates in the Waters of the Continental Shelf, U.S. Department of Energy, EY-87-S-02-2185 (1977).

6. Gorbushina, L. V., Tyminskiy, V.G. and Spiridenov, h.I., "significance of radiohydrogeological ananalies in a seismically active area for predicting earthquakes," Internat. Geology Rey. 15. 380-383 (1971).

7. Mavlyanov, G.A., Slittankhoozhayev, A. N., Gorbusinina, L. V., Tyminskiy, V.G., Spiridonov, A.I. and knasavova, L.A., "Role of radioisotope indicators of groundwater in determining earthquake precursors," Soviet Bydrology 1 , $94-97$ (1971).

8. Shishkevish, C., "Earthquake related rariatıon of microcomponents in thermal water of the Tashkent aquifer," Geosciences Bull. Series A $\underline{2}$, 69-91 (1971).

9. zverev, V.L., Dolidize, H.I., Spiridonov, A. I., Cheshko, A.L., and Chkenkeli, Sh. M., "An anamaly in the even-numberea isotopes of uranium in subsurface waters of seismically actlve regions of Georgia," Geokhimiya 11, 1720-1724 (1975).

10. Raleigh, B., Benrett, G., Craig, H., hanks, T., Molnar, P., Nur, A., Savage, J., Scholz, C., Turner, R., and Wu, F., "Prediction of the Haicheng Earthquake," EOS Trans. AGU 58, 236-272 (1977). 
11. Wakita, H., Nakamuza, Y., Viots', K., Hoguchi, Y., and Asada, T., "Radon anomaly: a possible precursor of the 1978 Izu-Cshima-kinkai earthquake," Science 207, 862-883 (i978).

12. Craig, H., Chung, Y., Lupton, j., Damasceno, S., and Poreda, R., lnvestigation of radon and helium as possible fluid phase precursors to earthquakes, U.S. Geological Survey, Menlo Park, C.:if., Tech. Rpt. No. :I (1979). Grant No. 14-08-0001-6-470, to Cniversity of Calatorni3, San Diego, Calif.

13. Kruger, R. and warten, G., "Radch in geothormal reservol engl neering," in Proc. Second workshop, Geothermal Reservoir Engineering, Stanford "nuversity, Palo Alto, 1976, Pp. 61-65.

14. Scholz, C.H., Sykes, L.R., and Aggarwal, Y., "Earthquake predictiot:: a phystcal asis," Science 181, 803-810 119:31.

15. King, C.Y., "Radon emanation un San hndreas Faut," Nature 271, $516.5:$ " (1978,.

16. hndrews. J.N. and hood, D.F., "Mechanism of radon releuse in : oce. matrices and entry into groundwaters," Trans. Inst. Mining Metal 81 , Bi $98-8209$ (19:2).

17. King, C.Y., "Geochemical measurements dertinent to earthquake predict. r,." J. Geophys. Res. 85, 3051 (1980).

18. Talwani, P., Moore, w.S., and Chiang, J., "Rader anomai es anr microearthquakes at iake Jocassee, South Cazolina," J. Geophys. Res. gj. $3079-3085$ (1980).

19. Mogro-Campern, A., Fleischer, R. L., and Likes, R. S., " hangez 1 n subsuriace radon concentration associated with aarthquakes," J. Geoprys. Res. B5, 3053-3057 (1980).

20. Teng, T.L., "Scme recent studies on groundwator racon cortent as as: earthquake precursor," J. Geophys. Res. 85, 3089-2099;:980; .

21. King, C.Y., "Episodic radon changes in subsurface soll jas zlorg active iauls and possitle relation to earthquakes," J. Geophys. Res. Es. $3065-3078(1980)$.

22. Liu, L.P., Kun, W.D., and Min, W.T., "Studies on forecasting eas:hquakes in the light of abnormal var'ation in kn concentration in grasrc..ater," Acta Geophys. Sinica I8, 27y-283 (1975). 
23. California Department of Water Resources, Reevaluation of seismic hazards for Clifton Court Forebay, Bethany Dams and Reservoir, Patterson Reservoir, Del Valle Dam and Lake Del Valle, State of California, Department of water Resources, Sacramento, Calif. (2979).

24. Mazor, E., "Noble gases in a section across the vapor-dominated geothermal field of Lardarello, Italy," Pure Appl. Geophys. 17, 262-275 (1978).

25. Kruger, P., Stoker, A., and Umana, A., "Radon in geotherma? reservoir engineering," Geothermics 5, 13-19 (1977).

26. Broecker, W.S. and Kaufman, A., "Near-surface and near-bottom radon results for the 1969 North Pacific Geosecs station, " J. Geophys. Res. 75, $7679-7681$ (1970).

27. Rogers, A.S., Physical behavior and geological control of radon in mountain streams, U.S. Geol. Surv. Bull. 1052E, Pp. 197-211 (1958).

28. Rama, "Using natural radon for delineating monsoon cicculation," J. Geophys. Res. 75, 2227-2229 (1970).

29. Wilkening, M.H., "Radon 222 concentrations in the convective patterns of a mountain environment," 3 . Geophys. Res. 75, 1733-1740 (1970).

30. Torgerson, T., "Controls on pore-fluid concentration of ${ }^{4}$ He and ${ }^{222}$ Rn and the calculation of ${ }^{4} \mathrm{He} /{ }^{222} \mathrm{Rn}$ ages," J. Geochem. Expl. 13, 57-75 (1980).

31. Nielson, D.L., Radon emanometry as a geothermal exploration technique. Earth Science Laboratory, University of Utah Research Institute, ESC-14 (1978).

32. Dyck, W. and Smith, A.Y., "Use of radon-222 in surface waters for uranium geochemical prospecting," Can. Mining. J. 64, 100-103 (1968).

33. Israel, H. and Bjornsson, S., "Radon and thoron in soil air over faults," Zeitschritt. Geophys. $3 \underline{3}, 48-64$ (1966). 
APFE:ADIX

FOJR SAMPLE WELIS IN THE IIVEMMTIEE AKEA

1. Wel1 BP

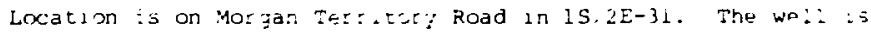
situated on the Marsh Creex. Diatio) Falit, approximately: 2 mi east of U.S.G.S. selsmometer CMO. : : was dr:lled $=0150 \mathrm{ft}$ in: $: 953$ and :s entirely in bedrock (marniy sandstone, Cretaceous Shasta Fmı. The we! I is puinped daly for domestic use. Water quaity and flow rate were affected by the January 24, 1980 event.

2. We11 BR

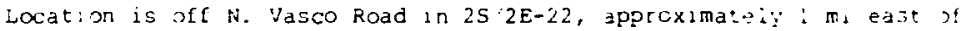
LiNL station CLO3. It is situatell athin the Greenville Fajit. system. approximately $1,4 \mathrm{mi}$ west of enechel 2 n crackina across $N$. Vasco $R d$.

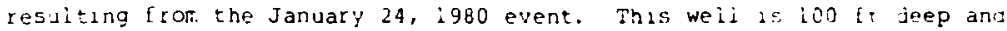
is artesian; it was actuall: drilled over an existing sprang. It as encirely within bedrock. mostlyc glomerate lTertiary Clerbo Fm!. Crf well is pumped daily for domestic and ilrestock use. Water quility and flow $t$ ate were affected by the Jamuary 24, 1980 event.

3. Weli TG

Location is off Patterson Pass Road in 35/3E-7, neal jiNL station PlGS. The well is situated within the Greenvilie Fault system at the intersection with the Las Positas Fa:it, and within tiuf ivormore syncline at a point adjacent to the Livermore ori field, oider zuaternary alluvium at surface, Tertiary Cierbo $F m$ at depthl. It was ar 11 led tu $130 \mathrm{ft}$ in 1951. The water 13 used for watering stock and : pumped da:iy. A high boron contert makes it unfit for human consumption. The holjing tank contained oily residue, apparently pumped from the wei: immesiately after the January 24,1980 event.

4. Well KD

Location is on Cross Road in 3S/3E-17. The well is situated within the Greenville Fault system on a shor: faulted segment transverse to the Greenville Fault trend, but supparallei to the Las Positas Fault colder Quaternary alluvium at surface, Livermore Fm gravels at depth). The weli is $240 \mathrm{ft}$ deep and the well pipe was broken during the January 24, 1980 event. 